\section{Method for the demonstration of nucleoli in lymphocytes and other blood and bone marrow cells}

\author{
E. M. GILLIS ${ }^{1}$ and A. G. BAIKIE ${ }^{2}$ From The Medical \\ Research Council Clinical Effects of Radiation \\ Unit, Western General Hospital, Edinburgh
}

Methods hitherto available for the staining of nucleoli in dried films of blood and bone marrow are generally unsatisfactory. The various Romanowsky stains as used for routine purposes sometimes reveal nucleoli in leukaemic blast cells in the peripheral blood and in haemocytoblasts, megaloblasts, myeloblasts, and promyelocytes in the bone marrow. When stained by these methods the nucleoli are only roughly outlined and internal structure is rarely revealed. The demonstration of nucleoli in normal lymphocytes of peripheral blood is especially unsatisfactory. The belief is still widely held that these cells do not have nucleoli and if any are seen in Romanowsky-stained preparations the cells are often regarded as abnormal on that account. The special stains recommended for the demonstration of nucleoli afford only marginal advantages with both normal and abnormal blood cells. In our hands the methyl-greenpyronin technique (Perry and Reynolds, 1956) has never given good results with blood or bone marrow and has served only to demonstrate aggregates of pyroninpositive material in a small proportion of normal peripheral blood lymphocytes. Using the Feulgen method (Gardikas and Israëls, 1947-48) nucleoli can be seen as Feulgen-negative areas in the nuclei of a greater proportion of normal lymphocytes and monocytes but positive staining and demonstration of structure are lacking. A technique described by Greig (1959), in which dilute Romanowsky stain is used after acid hydrolysis, is more consistent than the Feulgen method but otherwise gives similar results. Acridine orange fluorescence generally gives a metachromatic colour differentiation between D.N.A. and R.N.A. and yet it is not completely successful in the demonstration of the nucleoli of blood cells (Jackson, 1961).

'Present Address: Unilever Research Laboratory, The Frythe, Welwyn, Herts.

${ }^{2}$ Present Address: University of Mtlbourre Dspartment of Medicine, St. Vincent's Hospital, Melbourne, Australia.

Received for publication 10 December 1963.
The effects on Romanowsky-type staining of the addition of acid dyes, particularly chromotrope $2 R$, were recently reported by Menzies (1962). Using a chromotrope-Giemsa stain he showed accentuation of nucleolar staining in the large nuclei of the cells of the Walker rat carcinoma. As used by Menzies on this material the method gave only poor results with smears of blood and bone marrow. We now describe a modification of his method for use with blood films, bone marrow smears, and lymph node imprint preparations and give a preliminary account of the results obtained.

\section{METHOD}

A stock solution of $1 \%$ chromotrope 2R (British Drug Houses Ltd.) in distilled water is prepared.

A working solution consists of 4 parts of improved Giemsa R66 (George T. Gurr Ltd.), 1 part of $1 \%$ chromotrope $2 \mathrm{R}$, and 5 parts of distilled water. This solution may either be used immediately or may require to stand for up to 30 minutes before use. The optimal standing time has to be found for each batch of Giemsa stain.

Thin blood films are air dried and then fixed in methanol for three minutes.

After fixation and without rinsing the films are stained in the working solution for five to eight minutes, the time varying with batches of Giemsa.

After rinsing in buffer $p \mathrm{H} 6.8$ (Dacie, 1956) the films are differentiated in the same buffer solution for 10 to 20 minutes. The end-point is decided upon by frequent microscopical examination.

Bone marrow smears and imprint preparations of lymph nodes require to be fixed for five minutes and differentiation may require up to $\mathbf{3 0}$ minutes.

\section{RESULTS}

The most strikingly successful use of the method so far has been in the demonstration of nucleoli in the peripheral blood lymphocytes of normal subjects (Fig. 1 and Table). They can be seen clearly in from 91 to $98 \%$ of these cells, large or small. Some of the few lymphocytes without discrete nucleoli have nuclear dots and strands with the same staining reaction. The lymphocyte nucleoli vary in shape from round to almost triangular and a composite structure can be discerned in many. In abnormal cells with larger nucleoli, such as the blast cells of acute leukaemia (Fig. 2) and megaloblasts in bone marrow (Fig. 3), details of this composite structure are even more clearly seen. In some of these abnormal

TABLE

NUCLEOLI IN 100 LYMPHOCYTES IN PERIPHERAL BLOOD FILMS FROM 15 NORMAL SUBJECTS

Normal Subjects

\begin{tabular}{|c|c|c|c|c|c|c|c|c|c|c|c|c|c|c|c|c|}
\hline & & \multicolumn{15}{|c|}{ Normal Subjects } \\
\hline & & 1 & 2 & 3 & 4 & 5 & 6 & 7 & 8 & 9 & 10 & 11 & 12 & 13 & 14 & 15 \\
\hline Small lymphocytes & $\begin{array}{l}\text { No nucleolus } \\
1 \text { nucleolus } \\
2 \text { or more nucleoli }\end{array}$ & $\begin{array}{r}3 \\
64 \\
6\end{array}$ & $\begin{array}{r}3 \\
64 \\
4\end{array}$ & $\begin{array}{r}2 \\
42 \\
13\end{array}$ & $\begin{array}{r}7 \\
46 \\
2\end{array}$ & $\begin{array}{r}2 \\
73 \\
12\end{array}$ & $\begin{array}{r}2 \\
59 \\
3\end{array}$ & $\begin{array}{r}4 \\
53 \\
0\end{array}$ & $\begin{array}{r}6 \\
44 \\
2\end{array}$ & $\begin{array}{r}2 \\
41 \\
2\end{array}$ & $\begin{array}{r}2 \\
47 \\
1\end{array}$ & $\begin{array}{r}4 \\
46 \\
8\end{array}$ & $\begin{array}{r}2 \\
30 \\
6\end{array}$ & $\begin{array}{r}2 \\
52 \\
4\end{array}$ & $\begin{array}{r}3 \\
40 \\
6\end{array}$ & $\begin{array}{r}2 \\
44 \\
0\end{array}$ \\
\hline Medium or large lymphocytes & $\begin{array}{l}\text { No nucleolus } \\
1 \text { nucleolus } \\
2 \text { or more nucleoli }\end{array}$ & $\begin{array}{r}2 \\
19 \\
6\end{array}$ & $\begin{array}{r}1 \\
25 \\
3\end{array}$ & $\begin{array}{r}1 \\
35 \\
7\end{array}$ & $\begin{array}{r}2 \\
41 \\
2\end{array}$ & $\begin{array}{r}0 \\
13 \\
0\end{array}$ & $\begin{array}{r}0 \\
31 \\
5\end{array}$ & $\begin{array}{r}1 \\
40 \\
2\end{array}$ & $\begin{array}{r}1 \\
45 \\
2\end{array}$ & $\begin{array}{r}1 \\
54 \\
0\end{array}$ & $\begin{array}{r}3 \\
46 \\
1\end{array}$ & $\begin{array}{r}0 \\
38 \\
4\end{array}$ & $\begin{array}{r}0 \\
51 \\
11\end{array}$ & $\begin{array}{r}0 \\
35 \\
7\end{array}$ & $\begin{array}{r}0 \\
47 \\
4\end{array}$ & $\begin{array}{r}0 \\
41 \\
13\end{array}$ \\
\hline
\end{tabular}




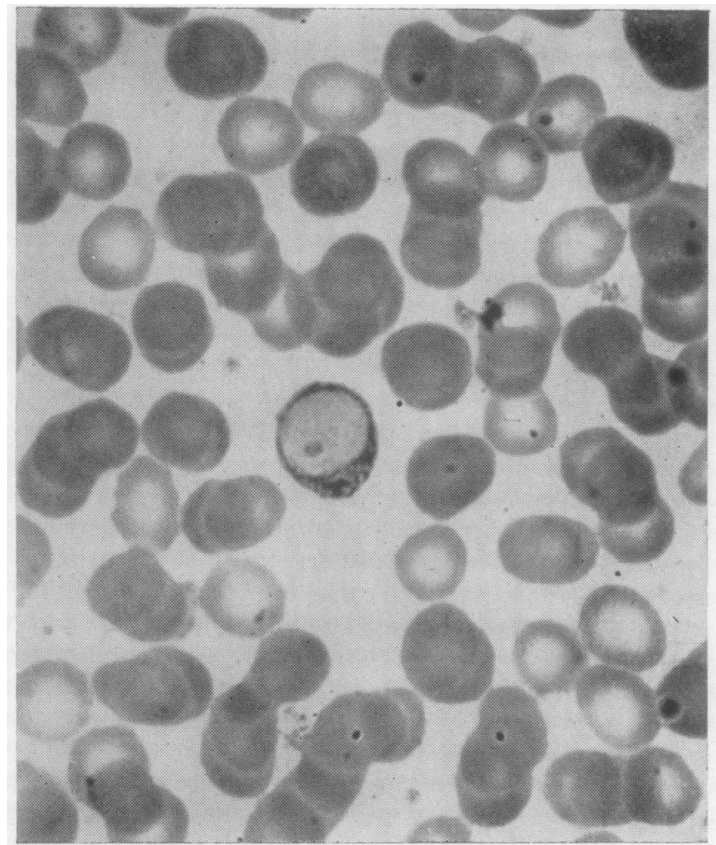

FIG. 1. Small nucleolus in normal small lymphocyte in peripheral blood $(\times 1,000)$.

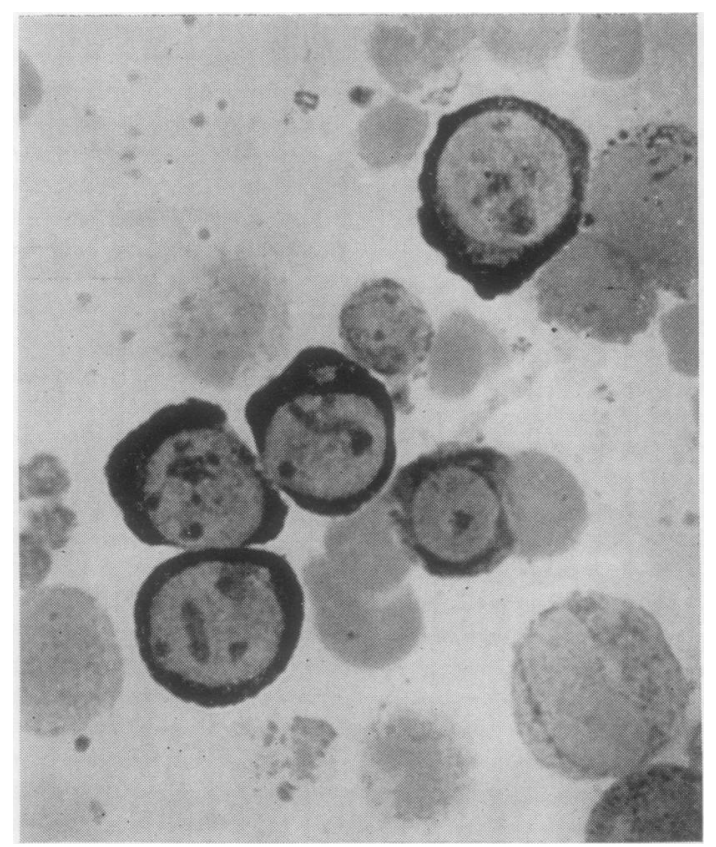

FIG. 2. Compound nucleoli in leukaemic blast cells in peripheral blood $(\times 1,000)$.

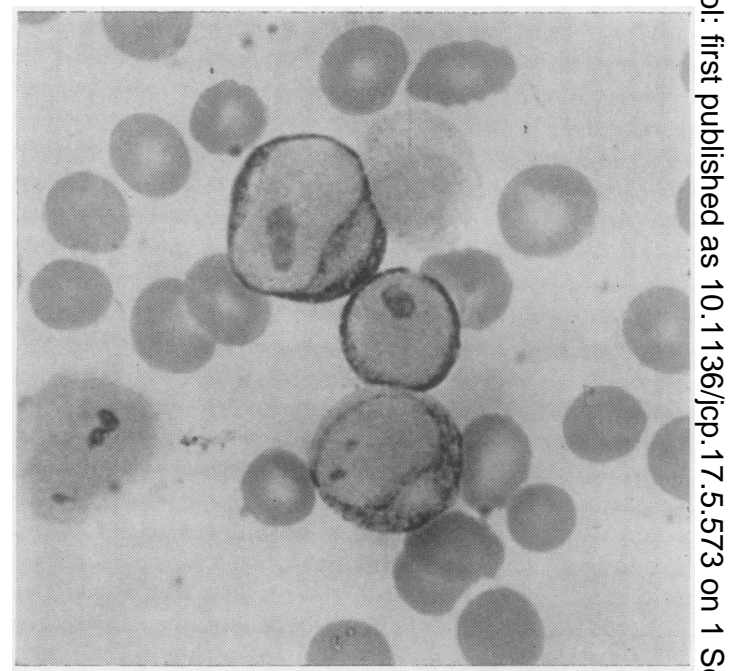

FIG. 3. Compound nucleoli of irregular outline in boneठ marrow megaloblasts $(\times 1,000)$.

cells the details of nucleolar structure seem hardly less clear than those revealed by electron microscopy (Bessis. and Thiery, 1961). Nucleoli may be demonstrated by theo chromotrope-Giemsa stain where they are completely. masked in Romanowsky preparations, as in the case of normal lymphocytes. In abnormal cells such ass leukaemic blast cells where nucleoli are visible in Romanowsky-stained preparations they are larger, ando more clearly delineated with obvious structural detail $\frac{0}{\mathrm{D}}$ in preparations stained by the chromotrope-Giemsa 2 technique. It is not clear why nucleoli should be thus $\overrightarrow{\hat{\sigma}}$ partially or completely masked in Romanowsky prepara-3 tions yet demonstrable by phase microscopy and by electron microscopy (Ackerman, 1960).

In discussing the mechanism of the chromotrope Giemsa technique Menzies said that its nucleolaro staining was abolished by preliminary treatment witho ribonuclease, but nevertheless recommended that the stain should nor be regarded as a specific R.N.A. indicator. However that may be, as modified for use with blood and bone marrow its staining reactions in cytoplasm correlate closely with cytoplasmic basophilia seen in Romanowsky preparations, as well as demonstrating nucleoli much more clearly.

We wish to thank Dr. D. W. Menzies of the Departmento of Pathology, University of Melbourne, for his advicen and criticism, and Mr. J. Paul of the Medical Photography Unit, University of Edinburgh, for the photographs.

\section{REFERENCES}

Ackerman, G. A. (1960). In The Lymphocyte and Lymphocytic Tissue, edited by J. W. Rebuck, pp. 28-53. Hoeber, New York. Bessis, M., and Thiery, J-P. (1961). Int. Rev. Cytol., 12, 199.

Dacie J. V (1956). Practical Haematology, 2nd ed Churchill, London Gardikas, C., and Israëls, M. C. G. (1947-48). J. clin. Path., 1, 226. Greig, H. B. W. (1959). J. clin. Path., 12, 93. Jackson, J. F., (1961). Blood, 17, 643.

Menzies, D. W. (1962). Stain Technol., 37, 45.

Perry, S., and Reynolds, J. (1956). Blood, 11, 1132. 
doctors anxious to grasp the implications of this development, but it could be helpful to the few already grappling with bio-medical electronics and familiar with computer jargon. It should be of great value to those scientists engaged in the engineering of computers and related equipment. Most of the discussion is orientated around the application of computer techniques to the problem of automatically recording and interpreting electrocardiograms. This is a particularly difficult field but it serves well to illustrate that all those contemplating making use of a computer must formulate their problems in very exact terms.

This book is well produced and has an adequate index. Whether the verbatim presentation is preferable to a conventional report is a matter of opinion but the reviewer found the text stimulating and easy to assimilate. This is a book to be bought by the progressive medical library rather than by the individual pathologist.

$$
\text { F. V. FLYNN }
$$

A SYNOPSIS OF SURGICAL PATHOLOGY By Wilfred Kark. (Pp. 426; 26 figures. 45s.) Bristol: John Wright. 1964.

This pocket-sized book of lecture notes on surgical pathology contains unavoidable simplifications and omissions. Pathologists will regret these, but know how difficult it is to report pathological changes succinctly and completely, and will realize that Mr. Wilfred Kark often succeeds brilliantly with his brief descriptions of the morbid anatomy and histopathology of surgical diseases. The didactic annotated text can be read quickly and a lot of uncontroversial information obtained in a short time.

In this country the teaching of pathology is becoming more closely integrated with that of clinical practice, and few students should find this book essential. Pathologists are more likely to recommend it to their senior technician who helps with the surgical specimens than to medical students, and the fate of this new synopsis will depend upon the amount of goodwill it can generate among students who read this at the eleventh hour before their final examinations.

R. A. B. DRURY

\section{PROTIDES OF THE BIOLOGICAL FLUIDS}

The 13th annual colloquium on the Protides of the Biological Fluids will be held in Bruges on 29-30 April and 1-2 May 1965. Topics to be discussed are lipoproteins, proteins of the nervous system, and impedance measurements of the proteins. At 'round tables' the subjects to be discussed are the physical, chemical, and clinical method of lipoprotein analysis, and the proteins of the nervous system.

All information may be obtained from:-COLLOQUIUM, Protides of the Biological Fluids, जP.B. 71, Bruges, Belgium.

\section{Letter to the Editor}

Sir,

The report on exertional haemoglobinuria in the September 1964 issue of the Journal adds substance to an hypothesis proposed many years ago. In 1903 in the Transactions of the Royal Medical and Chirurgical Society of London (volume 86, page 165), C. W. Ensor and J. O. W. Barratt presented a case of 'Paroxysmal haemoglobinuria of traumatic origin'. The patient, a young man with schizophrenia, would lie on his hospital bed violently slapping his forehead for an hour or two, and haemoglobinuria would appear thereafter. The loss of haemoglobin was equivalent to that in 2 or $3 \mathrm{ml}$. of blood. This is, I believe, the only reported case of exertional haemoglobinuria associated with exercise of the upper extremities only. Ensor and Barratt proposed that the haemolysis occurred with the injuring of red cells by the violent slapping, a suggestion which anticipates Dr. Davidson's that exertional haemoglobinuria in runners results from mechanical damage to red cells in the soles of the feet.

$$
\begin{array}{r}
\text { Sincerely yours, } \\
\text { William H. Crosby, } \\
\text { Colonel, M.C. } \\
\text { Chief, Department of Hematology, } \\
\text { Walter Reed Army Medical Center, } \\
\text { Washington, D.C. }
\end{array}
$$

CORRECTIONS

Professor I. Friedmann (J. clin. Path., 18, 63-68) writes that his attention has been drawn to another case of rhabdomyosarcoma of the ear in a girl of 4 years which was described by Professor Dorothy Russell in her book written jointly with L. J. Rubenstein ('Pathology of tumours of the nervous system', 1st ed., 1959, page 215). This case has not been described separately in any journal.

In the note on page 134 (J. clin. Path., 18, 1965) it is stated that at the Midland Centre for Neurosurgery determinations of creatine kinase are being regularly carried out by Dr. D. A. Ellis with the support of the Muscular Dystrophy Group. While it is quite true that the Muscular Dystrophy Group have most generously supported Dr. Ellis in research on muscular dystrophy, the determinations of creatine kinase are carried out by Dr. R. A. Westhead in the Centre's biochemistry laboratory without assistance from the Muscular Dystrophy Group.

In the September issue of the paper by A. G. Baikie and E. M. Gillis (J. clin. Path., 17, 573-574) we regret that Figures 2 and 3 have been transposed. 